\title{
Pengelolaan Kesan Citra Diri Pekerja Seks Komersial Pinggir Jalan Di Kota Medan
}

\section{Management of Self Image Impression of Commercial Sex Workers Roadside In Medan City}

\author{
Angelia Putriana \\ Pascasarjana Universitas Sumatera Utara \\ ${ }^{*}$ Corresponding author: E-mail: angelia@gmail.com
}

\begin{abstract}
Abstrak
Penelitian ini berjudul Pengelolaan KesanCitra Diri Pekerja Seks Komersial Pinggir Jalan di Kota Medan. Tujuan penelitian ini adalah untuk menggambarkan pengelolaan kesan citra diri pekerja seks komersial pada pelanggan, keluarga dan lingkungan sekitar. Penelitian ini menggunakan metode penelitian kualitatif dan unit analisis pekerja seks komersial pinggir jalan di Kota Medan dengan menggunakan metode purposive sampling. Pengumpulan data dilakukan kurang lebih selama 2 bulan. Temuan penting penelitian ini adalah pengelolaan kesanCitra Diri Pekerja Seks Komersial Pinggir Jalan di Kota Medan. Gambaran dari pengelolaan kesan pekerja seks komersial yaitu untuk menarik pelanggan, menutupi diri dari keluarga dan lingkungan sekitar yang tidak mengetahui pekerjaannya. Kelima informan mengungkapkan bahwa menjadi PSK bukanlah pilihan yang sebenarnya tetapi ketidakmampuan mereka untuk melakukan pekerjaan lain yang lebih menguntungkan menjadikan PSK adalah lebih baik.
\end{abstract}

Kata Kunci: Impression Management; Citra Diri; Pekerja Seks Komersial.

\begin{abstract}
This research entitled Impression Management Street Prostitute's Self Image in Medan City. The purpose of this research is to describe Impression Management Prostitute's Self Image to customers, family and the environment. This reseacrh uses qualitative research methods and the analysis unit is street prostitutes in Medan city with purposive sampling method. Data is collected in approximately 2 month. Important findings of this research is impression management and street prostitute's self image in Medan city. The illustration of prostitute's self image is to lure custumers, covering oneself from family and the environment that is not aware of the job. All five informants revealed that being a prostitute is not their actual choice of life but their unability to do other job which is more profitable makes prostitution a better choice.
\end{abstract}

Keywords: Impression Management; Self Image; Prostitute.

How to Cite: Putri, A. 2017, Pengelolaan Kesan Citra Diri Pekerja Seks Komersial Pinggir Jalan Di Kota Medan, Jurnal Simbolika, 3 (1): 1-. 


\section{PENDAHULUAN}

Manusia

pada

umumnya

membutuhkan pekerjaan atau profesi sebagai salah satu komponen agar bisa mendapatkan upah berupa uang guna memenuhi kebutuhan untuk kehidupan manusia itu sendiri setiap harinya.Pekerjaan adalah suatu kegiatan atau tindakan yang menghasilkan sesuatu yang biasanya berupa materi. Pekerjaan dapat dikelompokkan menjadi dua yaitu pertama, pekerjaan yang menuntut keahlian dan pendidikan khusus seperti guru dan dokter. Kedua, pekerjaan yang tidak memerlukan keahlian dan pendidikan khusus seperti kuli bangunan. Pekerja Seks Komersial merupakan bagian dari pekerjaan yang tidak memerlukan keahlian.

Pekerjaan atau profesi merupakan sumber utama untuk menghasilkan uang serta meraih status dalam bermasyarakat, namun adanya pekerjaan dan jabatan tidak semuanya memiliki nilai derajat yang tinggi. Terkadang profesi juga bisa membawa individu lebih rendah daripada hewan dikarenakan ada beberapa pekerjaan yang tidak baik dan di larangan oleh negara, setiap orang bisa bekerja apapun tanpa larangan, namun harus disesuaikan dengan kemampuan yang dimiliki diri sendiri. Kemampuan yang berbeda ini menyebabkan pekerjaan itu menjadi beragam dan timbul pekerjaanpekerjaan yang baru, buruk dan baik.

Kemampuan seseorang yang berbeda ini membuat setiap individu memilih pekerjaannya sesuai dengan kemampuannya seperti halnya seseorang yang memilih bekerja sebagai Pekerja Seks Komersial (PSK). Pekerja Seks Komersial berarti seseorang yang bekerja dengan menjual dirinya demi uang. Dari sudut pandang antropologi ekonomi, PSK memerlukan uang untuk memenuhi kebutuhan hidup dan PSK sering kali dianggap membahayakan kepribadian seseorang dan memperburuk kehidupan keluarga dan pernikahan menyebarkan penyakit dan mengakibatkan diorganisasi sosial, (Koentjoronigrat 2004 : 41). Terkait hal diatas, keterbatasan lapangan pekerjaan bagi perempuan dan keharusan mereka menjadi penyokong ekonomi keluarga yang pada akhirnya memilih pekerjaan demikian.

Pekerja Seks Komersial (PSK) merupakan salah satu pekerjaan ilegal, pekerjaan yang dilarang oleh negara, dimana banyak orang-orang yang terjun didalamnya dengan berbagai alasan atau motif. Motif menjelaskan alasan mengapa orang menghabiskan waktu mereka untuk mengerjakan sesuatu yang mereka inginkan. Seseorang memiliki motif akan cenderung mengulang-ulang perhatian kepada tujuan yang mendorong, mengorientasikan danmenyeleksi perilakunya. Dengan demikian, pada dasarnya kecenderungan motif mengacu pada pikiran akan suatu tujuan, sering kali muncul sebagai hal yang tengah menjadi perhatian (Koentjoro, 2004: 48-49).

Berdasarkan defenisi diatas dapat disimpulkan bahwa yang menjadi motif dari para Pekerja Seks Komersial ini adalah uang namun tidak bisa dipungkiri bahwa motif selain uang juga bisa saja ada. Motif tersebut timbul dari latar belakang yang berbeda dari setiap Pekerja Seks Komersial. Para ahli telah berusaha merumuskan defenisi pelacuran yang memadai. Beberapa ahli menemukan adanya komponen utama yang dapat 
digunakan untuk mengembangkan defenisi pelacuran. Komponen utama tersebut adalah bayaran, perselingkuhan, dan ketidakacuhan emosional. Bayaran atas pelayanan seks adalah elemen paling mendasar dalam defenisi tentang pelacuran. Pelacur adalah seseorang menggunakan tubuhnya sebagai komoditas dan menjual seks dalam satuan harga tertentu, melakukan hubungan seks untuk uang dan selaku tindakan memperoleh uang demi Seks. Pekerja Seks Komersial adalah para pekerja yang bertugas melayani aktivitas seksual dengan tujuan untuk mendapatkan upah atau imbalan dari yang telah memakai jasa mereka tersebut ( koentjoro, 2004 :2930). Maka dapat disimpulkan bahwa Pekerja Seks Komersial merupakan kegiatan jual beli berupa seks dengan tujuan memperoleh uang yang melibatkan banyak pihak.

Prostitusi bukan merupakan sebuah fenomena baru yang ada di dunia ini khususnya di Indonesia, kegiatan prostitusi nyatanya telah muncul sejak zaman kerajaan, kegiatan prostitusi sendiri tidak lepas dari kebudayaan patriarki yang dulunya berkembang di Indonesia yang lambat laun memunculkan definisi sosial bahwa perempuan adalah objek seksual, bahkan pada zaman itu perempuan dianggap sebagai hadiah atau objek paling berharga yang dapat diberikan seseorang kepada rajanya. Zaman penjajahan nyatanya tidak membuat kegiatan prostitusi berhenti, bahkan kegiatan prostitusi mengalami peningkatan pada saat zaman penjajahan Belanda yang saat itu dipimpin oleh J.P.Coen yang langsung mendatangkan germo dari Perancis dan China serta mendatangkan para pekerja seksnya dari Macao dengan tujuan untuk menghibur para tentara Belanda, sekaligus digunakan sebagai tempat persinggahan bagi orangorang China kaya pada saat itu. Dilihat di era serba maju seperti sekarang, nyatanya praktik prostitusi justru berkembang semakin pesat, hal tersebut disebabkan oleh banyak faktor antara lain, demi menghindari kesulitan hidup atau istilahnya mengambil "jalan pintas" untuk memenuhi kondisi ekonomi, lalu arus urbanisasi yang semakin tinggi menyebabkan sulitnya mencari pekerjaan di kota-kota besar, sedangkan faktor lainnya terjadi akibat aspirasi materiil yang tinggi pada wanita-wanita yang menyukai barang-barang mewah namun memiliki penghasilan kurang memadai/malas bekerja, sehinggaperempuan-perempuan itu memutuskan untuk bekerja di dunia prostitusi (Kartono, 2011 : 10).

Para Pekerja Seks Komersial mempunyai berbagai istilah di Indonesia antara lain cewek orderan, pelacur, sundal, wanita tuna susila, ayam kampus, cewek bispak, lonte, mucikari serta Pekerja Seks Komersial, setiap nama-nama tersebut sebenarnya memiliki pengertian yang sama hanya saja dibuat untuk memperhalus panggilan mereka sehingga terlihat lebih manusiawi. Ini artinya para perempuan itu adalah orang yang tidak bermoral karena melakukan suatu pekerjaan yang bertentangan dengan nilainilai kesusilaan yang berlaku dalam masyarakat. Oleh karena pandangan semacam ini, para pekerja seks mendapat cap buruk (Stigma) sebagai orang yang kotor, hina, dan tidak bermartabat. Tetapi orang-orang yang memperkerjakan 
mereka dan mendapatkan keuntungan besar dari kegiatan ini tidak mendapatkan cap yang demikian. Jika dilihat dari pandangan yang lebih luas. Kita akan mengetahui bahwa sesungguhnya yang dilakukan pekerja seks adalah suatu kegiatan yang melibatkan tidak hanya si perempuan yang memberikan pelayanan seksual dengan menerima imbalan berupa uang.

Tetapi ini adalah suatu kegiatan perdagangan yang melibatkan banyak pihak dengan berbagai fenomena dan kisah yang berbeda. Berdasarkan undangundang Republik Indonesia no 44 tahun 2008 tentang pornografi. Tidak hanya undang-undang yang menjadikan pekerjaan tersebut ilegal, didalam agama Islam, hindu, Yahudi dan Kristen juga melarang pekerjaan tersebut yang dimana keempat agama tersebut menjelaskan bahwa pekerjaan PSK adalah sebuah zina dan orang yang terkutuk. Tidak hanya secara agama dan undang-undang menyatakan pekerjaan ini buruk, secara kesehatan juga menjelaskan penyakit yang dapat ditimbulkan oleh aktivitas pekerjaan ini adalah Penyakit Menular Seksual (PMS).

Penyakit ini disebut juga venereal, berasal dari kata venus, yaitu Dewi Cinta dari Romawi kuno. Penularan penyakit ini biasanya terjadi karena seringnya seseorang melakukan hubungan seksual dengan berganti-ganti pasangan (Dianawati,2003:86).Penyakit Menular Seksual (PMS) merupakan salah satu infeksi saluran reproduksi (ISR) yang ditularkan melalui hubungan kelamin. Kuman penyebab infeksi tersebut dapat berupa jamur, virus dan parasit. Perempuan lebih mudah terkena infeksi saluran reproduksi (ISR) dibanding dengan lakilaki, karena saluran reproduksi perempuan lebih dekat ke anus dan saluran kencing. ISR pada perempuan juga sering tidak diketahui karena gejalanya kurang jelas dibandingkan laki-laki (Widyastuti,2009:38).Kesehatan adalah keadaan sejahtera dari badan, jiwa, dan sosial yang memungkinkan setiap orang hidup produktif secara sosial dan ekonomis (Anonima, 2004). Berdasarkan pengertian kesehatan diatas, jelas diterangkan bahwa Pekerja Seks Komersial merupakan pekerjaan yang sangat beresiko tinggi bagi kesehatan.

Pekerjaan yang cukup beresiko tinggi ini terus berkembang, tidak hanya pekerjanya, namun konsumen dari pekerjaan ini juga meningkat bahkan menurut hasil statistik diperkirakan sampai dengan tahun 2013 jumlah Pekerja Seks Komersial yang tersebar di berbagai lokalisasi yang ada di Indonesia telah mencapai jumlah yang fantastis, yaitu kurang lebih sekitar 40.000 orang (Tempo, 2013). Sedangkan pada tahun 2016 menurut direktur rehabilitasi Tuna Susila, Sony W. Manalu jumlah Pekerja Seks Komersial yang tersebar di 164 lokalisasi yang ada di seluruh Indonesia telah mencapai jumlah yang fantastis, yaitu mencapai 56.000 orang (Merah Putih, 2015). Menurut Unicef 30 persen dari Pekerja Seks Komersial di Indonesia masih dibawah umur 18 tahun. Selain itu, ada Pekerja Seks Komersial diluar dari lokalisasi yang berjumlah tiga kali lipat dari 56.000 orang. Terdapat tiga kategori Pekerja Seks Komersial di Indonesia yaitu pertama, kelompok perempuan cantik yang memilih profesi menjajakan diri dengan bayaran yang sangat tinggi. Kedua, 
Grup Pekerja Seks Komersial yang menjajakan diri mereka ditemani dengan mucikari dan biasanya ditemukan di tempat lokalisasi. Ketiga, kelompok pelacur yang dengan sungguh-sunguh menjajakan diri karena terdesak masalah ekonomi (Koran Sindo, 2016).

Pekerja Seks Komersial ini dapat di temui dengan sangat mudah dan bahkan sekarang para Pekerja Seks Komersial sudah sangat terang-terangan menampakkan dirinya di depan publik. Pekerja Seks Komersial bukan merupakan hal yang tabu lagi untuk dijaman sekarang ini yang berbeda dengan jaman dulu yang keberadaan dari Pekerja Seks Komersial masih dilakukan sembunyi-sembunyi. Peneliti mencoba mengungkap bagaimana seorang Pekerja Seks Komersial melakukan pengelolaan kesan didepan pelanggan dan orang-orang disekitarnya. Terkadang, kita dapat belajar dari orang yang buruk sekalipun, pemikiran demikianlah yang membawa peneliti meneliti Pekerja Seks Komersial. Melalui penelitian ini, peneliti juga akan mencoba menggambarkan beberapa hal yang mungkin banyak tidak diketahui oleh masyarakat.

Penelitian ini dilakukan di Medan. Medan merupakan kota besar sehingga sangat cocok untuk dilakukannya penelitian terkait dengan Pekerja Seks Komersial. Keberadaan Pekerja Seks Komersial di kota Medan dapat di temui di beberapa daerah di jam 21.00 WIB keatas di jalan gajah mada, selayang, jalan nibung, simpang barat, aksara dan lain-lain. Penelitian ini akan dilakukan di beberapa jalan tersebut dengan mengambil satu informan dari setiap lokasi yang nantinya dapat mewakili populasi yang ada.
Penghasilan yang diperoleh cukup beragam dan bervariasi dan biasanya dibayar sesuai dengan kondisi ekonomi negara masing-masing. Untuk di daerah Medan saja, satu orang Pekerja Seks Komersial bisa memperoleh uang puluhan juta bahkan ada yang ratusan ribu per bulan, minggu dan hari namun untuk di pinggir jalan sendiri minimal bisa mendapat tiga ratus ribu rupiah per hari.

Pekerja Seks Komersial (PSK) yang memiliki klien asing, seperti pelancong bisnis, tergantung pada kondisi ekonomi luar negeri yang baik. Pembayaran dapat bervariasi sesuai dengan peraturan yang dibuat oleh pemilik bordil, nyonya dan germo, yang biasanya mengambil sepotong dari penghasilan seorang pelacur. Namun jika seorang Pekerja Seks Komersial (PSK) tersebut berdiri sendiri atau tidak memiliki germo maka penghasilan yang diperolehnya seutuhnya miliknya. Harga mungkin lebih tergantung pada permintaan misalnya kepopuleran dari PSK, Pekerja Seks Komersial (PSK) kelas atas bisa mendapatkan sejumlah besar uang dan harga lebih tinggi diberikan kepada pelacur yang masih perawan. Untuk harga Pekerja Seks Komersial (PSK) yang kelas rendah mendapatkan jumlah uang yang tidak terlalu banyak seperti PSK kelas atas karena para pekerja yang kelas rendah konsumennya adalah menengah kebawah.

Penelitian ini akan meneliti Pekerja seks Komersial yang kelas rendah karena para pekerja seks yang kelas rendah ini sering menjadi korban para Satuan Polisi Pamong Praja (SatPol PP) atau mungkin direndahkan oleh warga sekitar. Berbeda dengan pekerja seks yang kelas atas sangat pandai sekali dalam 
menyembunyikan diri dan tidak pernah menjadi korban SatPol PP. Pekerja seks kelas atas akan lebih baik dalam mengelola kesan daripada pekerja seks komersial kelas bawah dan hal ini membuat peneliti tertarik untuk meneliti pekerja seks komersial kelas rendah yang kemungkinan dalam penelitian ini peneliti dapat menemukan satu hal unik dari pekerja seks komersial pinggir jalan (kelas rendah) ketika sedang melakukan pengelolaan kesan.

Penghasilan yang begitu menggiurkan dan menjanjikan seperti ini membuat seseorang tidak berpikir panjang untuk masuk ke dalam pekerjaan ini. Adapun yang menjadi alasannya adalah karena faktor ekonomi, pergaulan, gaya hidup, pernah menjadi korban pelecehan seksual, cara kerja yang hanya dengan bermodalkan tubuh sehingga mudah untuk dikerjakan. Mendapatkan sejumlah uang yang banyak tidaklah mudah, tentu mereka pernah mendapatkan perlakuan yang tidak baik dari pelanggan dan germonya. Sebagai contoh seorang Pekerja Seks Komersial (PSK) perempuan yang mempunyai germo, tentu saja penghasilan Pekerja Seks Komersial (PSK) dibagi dua dan juga terkadang germo mau memakai jasa pelayanan PSK tersebut dengan gratis. Perlakuan yang tidak menggenakkan sering di terima oleh para Pekerja Seks Komersial tersebut namun tetap saja banyak orang terjun didalamnya bahkan semakin hari semakin marak keberadaan dari Pekerja Seks Komersial (PSK) itu sendiri yang tersebar di seluruh dunia.

Pekerja seks komersial yang mempunyai konsep diri yang buruk juga berlomba-lomba untuk menampilkan sesuatu yang terbaik dari dirinya untuk diperlihatkan dihadapan orang lain. Kepedulian akan hal ini menuntun seseoranguntuk berusaha mengontrol apa yang orang lain pikir tentang diri orang tersebut. Imageyang coba ditampilkan ini dapat berbeda-beda dari satu situasi ke situasi yang lain tergantung dari tujuannya.Orang lain akan menilai pribadi seseorangberdasarkan petunjuk-petunjuk yang diberikan, dan darihasilpenilaian itulahmereka memperlakukan orang tersebut. Bila orang lain menilai seseorangberstatus rendah, maka orang tersebuttidak akan mendapatkan pelayanan istimewa. Dan bila dianggap bodoh, kemungkinan orang lainakan mengatur orang tersebut. Untuk itu, setiap orang sengaja menampilkan diri (selfpresentation) seperti yang dikehendakinya dan biasanya seseorang akan menampilkan hal-hal yang positif dan di senangi oleh orang lain.

Berbagai fenomena diatas membuat peneliti tertarik untuk meneliti terkait pengelolaan kesan citra diriseorang Pekerja Seks Komersial di depan pelanggan, keluarga dan lingkungan sekitarnya. Sebagaimana halnya seseorang yang buruk sekalipun menginginkan dirinya terlihat baik didepan orang lain apalagi orang yang mempunyai jabatan dan derajat kehidupan diatas yang tentu akan melakukan pengelolaan kesan citra diri.Pengelolaan kesan citra diri merupakan bagian dari mengelola kesan yang pada akhirnya membentuk sebuah persepsi pada orang lain.

Perilaku seseorang dalam berkomunikasi bergantung pada persepsi interpersonal. Karena perspsi yang keliru, seringkali terjadi kegagalan dalam 
komunikasi. Kegagalan komunikasi dapat diperbaiki bila orang tersebut menyadari bahwa persepsinya mungkin salah. Komunikasi interpersonal akan menjadi lebih baik bila mengetahui persepsi seseorang bersifat subjektif dan cenderung keliru. Biasanya seseorang jarang meneliti kembali persepsinya. Akibat lain dari persepsi yang tidak cermat ialah mendistorsi pesan yang tidak sesuai dengan persepsi kita. Persepsi kita tentang orang lain cenderung stabil, sedangkan persepsi stimuli adalah manusia yang selalu berubah. Adanya kesenjangan antara persepsi dengan realitas sebenarnya mengakibatkan bukan saja perhatian selektif, tetapi juga penafsiran pesan yang keliru. Sebuah persepsi yang timbul pada setiap pikiran manusia menyebabkan pengelolaan kesan terjadi. Persepsi dapat di bentuk, diperbaiki dengan melakukan pengelolaan kesan citra diri.

Studi ilmu komunikasi, pembentukkan kesan ini di kenal dengan istilah pengelolaan kesan. Goffman berpendapat bahwa pengelolaan kesan merupakan upaya presentasi diri yang digunakan aktor untuk memupuk kesankesan tertentu dalam situasi tertentu untuk mencapai tujuan tertentu (Mulyana, 2003 : 112). Tujuan yang ingin dicapai oleh setiap orang juga beragam tergantung kebutuhan setiap individunya, sebagai contohnya adalah seorang publik figur yang selalu menjadi sorotan media yang membuat mereka harus melakukan pengelolaan kesan karena pekerjaan mereka yang akan banyak orang melihat, meniru dan itu merupakan kebutuhan seorang publik figur agar mendapatkan perhatian dan simpati dari orang lain.
Tidak hanya publik figur, pejabat atau orang hebat lainnya yang melakukan hal demikian, namun khalayak biasa juga akan melakukan impresssion management tanpa sadari dan biasanya itu terjadi ketika bertemu dengan orang yang baru ditemui.

Pendekatan dramaturgi Erving Goffman berintikan bahwa ketika manusia berinteraksi dengan sesamanya, ia ingin mengelola kesan yang ia harapkan tumbuh pada orang lain terhadapnya. Untuk itu, setiap orang melakukan pertunjukkan bagi orang lain setiap harinya dan itu berlangsung secara terus menerus sampai orang yang melakukan pengelolaan kesan merasa bahwa ia masih membutuhkannya untuk keperluannya. Dalam kajian dramaturgi, kehidupan diibaratkan sebagai pertunjukkan drama karena setiap individu merupakan aktor dalam kehidupan. Kajian dramaturgi berintikan bahwa setiap aktor berperilaku bergantung pada peran sosialnya dalam situasi tertentu (Mulyana, 2003 :109). Konsep pengelolaan kesan Goffman lebih menekankan kepada proses komunikasi non verbal dengan menggunakan bahasabahasa non verbal seperti pakaian, gerakan tubuh, ekspresi wajah dan sebagainya.

Pengelolaan kesan dilihat dari depan panggung (front stage) pekerja seks komersial ketika sedang menggoda dan berinteraksi didepan masyarakat biasa atau lingkungan sekitarnya. Berdasarkan pengematan yang dilakukan oleh peneliti atas perilaku PSK, maka komunikasi verbal juga menjadi bagian penting dalam pengelolaan kesan yang dilakukannya. Artinya, bagaimana komunikasi verbal dan non verbal yang dilakukan oleh PSK 
dihadapkan oleh orang lain dalam setiap interaksi yang berbeda. Berlatar dari proses komunikasi yang dilakukan PSK tersebut, penelitian ini sesungguhnya bertujuan untuk melihat bagaimana pengelolaan pesan yang dilakukan oleh PSK dalam berdramatugis dalam hidup mereka.

Dramaturgis itu akan dilihat melalui pengelolaan pesan yang dibentuk PSK pada saat berada di kehidupan panggung depan yaitu ketika mereka berinteraksi dengan pria hidung belang yang ditunjukkannya melalui bahasa verbal dan non verbal. Tidak hanya ketika berinteraksi dengan para lelaki hidung belang, namun juga ketika berinteraksi dengan keluarga dan lingkungan sekitar. Selain itu penelitian ini juga akan mendeskripsikan bagaimana persiapan atau gambaran sesungguhnya Pekerja Seks Komersial tersebut saat berada dikehidupan panggung belakang yakni saat berada diluar aktivitas melacur yang dimana sangat erat kaitannya dengan citra diri dari seorang Pekerja Seks Komersial tersebut. Citra diri merupakan bagian dari pengelolaan kesan.

Citra diri dalam Burns (2003) adalah gambaran yang dimiliki seseorang tentang dirinya sendiri sebagai makhluk yang berfisik, sehingga citra diri selalu dikaitkan dengan karakteristikkarakteristik fisik termasuk didalamnya penampilan seseorang secara umum, ukuran tubuh, cara berpakaian, gaya rambut dan pemakaian kosmetik dimana hal tersebut dapat menggambarkan identitas diri dari seorang Pekerja Seks Komersial ketika melakukan pengelolaan kesan . Mendukung pernyataan diatas, citra diri merupakan konsep yang lengkap meliputi kepribadian, karakter, tubuh dan penampilan individu (Susanto, 2001: 50). Berdasarkan kedua pengertian ini, citra diri dapat disimpulkan sebagai gambaran seseorang tentang dirinya berdasarkan karakteristik fisik dan kepribadian yang melekat pada dirinya yang pada akhirnya menunjukkan identitasnya didepan orang lain. Biasanya orang melakukan sebuah pencitraan untuk membuat diri seseorang itu baik atau bahkan lebih baik dari orang lain.

Citra diri adalah cara anda melihat diri anda sendiri dan berpikir mengenai diri anda pada waktu sekarang ini. citra diri sering disebut juga sebagai cermin diri. Anda akan senantiasa melihat ke dalam cermin ini untuk mengetahui bagaimana anda harus bertindak atau berlaku pada suatu keadaan tertentu. Anda akan selalu bertindak dan bersikap sesuai dengan gambar yang muncul pada cermin diri anda. Perubahan yang paling cepat terjadi bila anda mengubah citra diri anda dengan cara yang berbeda, maka anda akan bertindak dengan cara yang berbeda. Bila anda bertindak berbeda maka anda akan merasa berbeda. Karena anda bertindak berbeda maka anda akan mendapatkan hasil yang berbeda (Gunawan, 2003 : 6-7). Terkait dengan citra diri yang ada pada pekerja seks komersial yang sangat beragam membuat peneliti tertarik untuk meneliti. Masyarakat umum memandang Pekerja Seks Komersial adalah pekerjaan yang buruk dan tidak mempunyai citra yang baik namun bagaimana dengan citra diri dari sudut pandang pekerjanya. Orangorang yang secara konsep diri tidak baik namun mereka menginginkan citra diri yang baik di depan orang lain. 
Pengelolaan kesan citra diri adalah dua hal yang sejalan dalam segi komunikasi yaitu orang yang melakukan pengelolaan kesan untuk mendapatkan sebuah citra diri yang diinginkan. Citra diri merupakan gambaran diri seseorang berdasarkan kacamata dirinya yang tentu pengelolaan kesan yang dilakukan untuk membentuk citra dirinya didepan orang lain. Para Pekerja Seks Komersial (PSK) mencoba membangun citra diri mereka dengan melakukan pengelolaan kesan di depan orang lain. Mencoba menata diri, membangun brand sendiri menjadi lebih baik dari orang lain atau sesama dia. Apalagi persaingan sesama Pekerja Seks Komersial (PSK) cukup banyak. Namun, hal ini tidak sejalan dengan nilai sebuah kejujuran karena adanya kemunafikan atau kepura-puraan, kejujuran tentang siapa diri kita sesungguhnya, tentang perasaan dan keyakinan dan sebenarnya. Namun demikian, anggapan seperti itu sebetulnya keliru. Aspek-aspek dari kepribadian yang menjadi identitas diri kita amatlah luas. Beliefs, values, competencies, dan traits adalah beberapa kategori yang dapat menunjukkan siapa diri kita apa adanya. Dalam interaksi sosial, orang lain perlu banyak waktu dan usaha untuk mengetahui semua itu dari diri kita.

Mengetahui gambaran diri sendiri dan orang lain tentu tidak mudah karena setiap orang mempunyai keterbatasannya ketika melihat gambaran dirinya dan orang lain maka dari itu penelitian ini akan mencoba melihat bagaimana pekerja seks komersial tersebut menggambarkan dirinya atau bercermin melihat siapa dirinya. Citra diri dapat di persepsikan oleh diri sendiri dan orang lain. Citra diri seseorang cukup beragam, ada pula orang yang menilai diri secara berlebihan sehingga kelihatan seperti orang sombong, angkuh atau merasa pintar pada hal sebaliknya. Cara penilaian diatas dapat menemukan kepribadian seseorang secara obyektif walaupun menurut perasaan orang lain tidak sesuai atau berbeda dengan yang lainnya. Kepribadian yang baik tentu mempunyai karakter yang berguna dalam kehidupan sehari-hari. Orang lain akan cepat mengetahui sifat maupun keadaan seseorang sehingga mudah ditebak oleh orang lain.

Keterbatasan waktu dan usaha seseorang untuk menilai orang lain menjadi sebuah kendala, tidak jarang orang lain jadi salah menilai tentang diri seseorang akibat keterbatasan artinya sulit bagi seseorang untuk menilai orang lain yang kadang kala ia juga tidak mengenal siapa dirinya . Belum lagi pengaruh-pengaruh internal yang sedang menggangu hidup, sehingga tidak dapat menampilkan sebagaimana mestinya. Apalagi kesan yang ingin mereka tonjolkan dan mereka bangun tidak sesuai dengan yang mereka inginkan karena image seorang Pekerja Seks Komersial (PSK) sudah tidak baik dari awalnya. Penelitian ini penting diteliti guna menambah pengetahuan pembaca dalam hal teori dan juga praktisnya.

$$
\text { Paradigma adalah basis }
$$

kepercayaan utama atau metafisika dari sistem berpikir : basis dari ontologi, epistemologi, dan metodologi. Ada tiga konsepsi paradigma, yakni : Positivisme / post-positivisme, konstruktivisme / interpretif dan paradigma kritis (Critical Theory). Paradigma adalah pandangan mendasar mengenai pokok persoalan, 
tujuan dan sifat dasar bahan kajian atau penelitian. Paradigma penelitian kualitatif dilakukan melalui proses induktif, yaitu berangkat dari konsep khusus ke umum. Konseptualisasi, kategorisasi dan deskripsi yang dikembangkan berdasarkan masalah yang terjadi dilokasi penelitian. Paradigma kualitatif mencanangkan pendekatan humanistik untuk memahami realitas sosial para idealis yang memberikan suatu tekanan pada pandangan yang terbuka tentang kehidupan sosial dan paradigm kualitatif ini memandang kehidupan sosial sebagai kreatifitas bersama individu-individu. Oleh karena itu, melalui paradigma kualitatif dapat menghasilkan suatu realitas yang dipandang secara objektif dan dapat diketahui yang melakukan interaksi sosial (Ghony dan Almanshur, 2012 : 73).

Kajian terdahulu merupakan penelitian yang sudah ada dan relevan dengan kajian yang akan diangkat namun terdapat perbedaan tertentu yang menjadikan kajian terdahulu menjadi sebuah perbandingan bagi peneliti. Kajian terdahulu dibutuhkan untuk menjadi bahan referensi dan sumber rujukan bagi seorang peneliti. Pada Bagian ini, peneliti akan memaparkan sekilas bahwa pada penelitian sebelumnya telah ada beberapa penelitian yang mengangkat permasalahan yang peneliti angkat yaitu penelitian kualitatif dengan pendekatan pengelolaan kesan atau Pengelolaan kesan. Meskipun dalam pendekatan dan landasan teori yang dipakai sama tentu saja dalam kesempatan ini peneliti ingin meneliti dalam masalah yang berbeda, mengungkap realitas kehidupan manusia dari sisi lain yang belum pernah ada (Alwasilah, 2002 : 125).

Teori merupakan landasan bagi penulis untuk memudahkan penulis dalam rangka menyusun penelitian ini. Kerangka teori dimaksudkan untuk memberikan gambaran atau batasan-batasan tentang teori-teori yang dipakai sebagai landasan penelitian yang akan dilakukan.Penelitian pada hakekatnya merupakan suatu upaya untuk menemukan kebenaran atau untuk lebih membenarkan kebenaran. Usaha untuk mengejar kebenaran dilakukan oleh para filosof, peneliti, maupun oleh para praktisi melalui model - model tertentu. Model tersebut biasanya dikenal dengan paradigma (Sugiyono, 2005:55).

Komunikasi antar pribadi sebenarnya merupakan suatu proses sosial dimana orang - orang yang terlibat di dalamnya saling mempengaruhi. Sebagaimana yang diungkapkan oleh DeVito (Liliweri, 2011:13) komunikasi antarpribadi merupakan pengiriman pesan-pesan dari seseorang dan diterima oleh orang yang lain atau sekelompok orang dengan efek dan umpan balik yang bersifat langsung.Orang memerlukan hubungan antarpribadi terutama untuk dua hal yaitu perasaan (Attachment) dan ketergantungan (Dependency).

Banyak hal yang menjadi faktorfaktor yang meningkatkan hubungan interpersonal, misalnya dari kwalitas komunikasi itu sendiri. Menurut Rakhmat (2005 : 130) faktor yang mempengaruhinya antara lain :

\section{Percaya (Trust)}

Dari berbagai faktor yang paling mempengaruhi komunikasi antar pribadi adalah faktor kepercayaan. Apabila antara suami dan istri memiliki rasa saling 
percaya maka akan terbina saling pengertian sehingga terbentuk sikap saling terbuka, saling mengisi, saling mengerti dan terhindar dari kesalahpahaman. Sejak tahap perkenalan dan tahap peneguhan, kepercayaan menentukan efektivitas komunikasi.

Sikap Terbuka

Sikap ini amat besar pengaruhnya dalam menumbuhkan komunikasi interpersonal yang efektif. Dengan komunikasi yang terbuka diharapkan tidak aka nada hal-hal yang tertutup, sehingga apa yang ada pada diri suami juga diketahui oleh istri, demikian sebaliknya. Dengan sikap saling percaya dan supportif, sikap terbuka mendorong timbulnya saling pengertian, saling menghargai, dan paling penting saling mengembangkan kualitas hubungan interpersonal. Walaupun berkomunikasi merupakan salah satu kebiasaan dengan kegiatan sepanjang kehidupan, namun tidak selamanya akan memberikan hasil seperti yang diharapkan.

Menemukan Dunia Luar

Hanya komunikasi interpersonal menjadikan kita dapat memahami lebih banyak tentang diri kita dan orang lain yang berkomunikasi dengan kita. Banyak informasi yang kita ketahui datang dari komunikasi interpersonal, meskipun banyak jumlah informasi yang datang kepada kita dari media massa hal itu seringkali didiskusikan dan akhirnya dipelajari atau didalami melalui interaksi interpersonal.

Membentuk Dan Menjaga Hubungan Yang Penuh Arti

Salah satu keinginan orang yang paling besar adalah membentuk dan memelihara hubungan dengan orang lain.
Banyak dari waktu kita pergunakan dalam komunikasi interpersonal diabadikan untuk membentuk dan menjaga hubungan sosial dengan orang lain.

Berubah Sikap Dan Tingkah Laku

Banyak waktu kita pergunakan untuk mengubah sikap dan tingkah laku orang lain dengan pertemuan interpersonal. Kita boleh menginginkan mereka memilih cara tertentu, misalnya mencoba diet yang baru, membeli barang tertentu, melihat film, menulis membaca buku, memasuki bidang tertentu dan percaya bahwa sesuatu itu benar atau salah. Kita banyak menggunakan waktu waktu terlibat dalam posisi interpersonal.

Untuk Bermain Dan Kesenangan

Bermain mencakup semua aktivitas yang mempunyai tujuan utama adalah mencari kesenangan. Berbicara dengan teman mengenai aktivitas kita pada waktu akhir pecan, berdiskusi mengenai olahraga, menceritakan cerita dan cerita lucu pada umumnya hal itu adalah merupakan pembicaraan yang untuk menghabiskan waktu. Dengan melakukan komunikasi interpersonal semacam itu dapat memberikan keseimbangan yang penting dalam pikiran yang memerlukan rileks dari semua keseriusan di lingkungan kita.

Untuk Membantu

Ahli-ahli kejiwaan, ahli psikologi klinis dan terapi menggunakkan komunikasi interpersonal dalam kegiatan profesional mereka untuk mengarahkan kliennya. Kita semua juga berfungsi membantu orang lain dalam interaksi interpersonal kita sehari-hari. Kita berkonsultasi dengan seorang teman yang putus cinta, berkonsultasi dengan 
mahasiswa tentang mata kuliah yang sebaiknya diambil dan lain sebagainya.

\section{METODE PENELITIAN}

Metodologi penelitian adalah suatu prosedur atau cara untuk mengetahui sesuatu yang mempunyai langkah-langkah sistematis, sedangkan metodologi ialah suatu pengkajian dalam mempelajari peraturan-peraturan suatu metode. Jadi metodologi penelitian adalah suatu pengkajian dalam mempelajari peraturanperaturan yang terdapat pada penelitian. Menurut Krisyantono, metodologi penelitian merupakan sekumpulan peraturan, kegiatan, dan prosedur yang digunakan oleh pelaku suatu disiplin ilmu. Metode penelitian ada beberapa jenis, namun penelitian ini menggunakan metode penelitian kualitatif studi kasus.

Studi kasus menurut Yin (2008:18) adalah suatu inquiri empiris yang menyelidiki fenomena dalam kontekskehidupan nyata, bilamana; batasbatas antar fenomena dan konteks tak tampak dengantegas dan di mana: multi sumber bukti dimanfaatkan. Sebagai suatu inquiry studi kasus tidak harus dilakukan dalam waktu yang lama dan tidak pula harus tergantung pada data etnografi atauobservasi partisipan. Bahkan menurut Yin seorang peneliti bisa saja melakukan studi kasus yang valid dan berkualitas tinggi tanpameninggalkan kepustakaan, tergantung pada topikyang akan diselidiki.

Menurut Stake (Creswell, 2010 : 20), Studi Kasus merupakan strategi penelitian dimana di dalamnya peneliti menyelidiki secara cermat suatu program, peristiwa, aktivitas, proses, atau sekelompok individu. Kasus-kasus dibatasi oleh waktu dan aktivitas,dan peneliti mengumpulkan informasi secara lengkap dengan menggunakan berbagai prosedur pengumpulan data berdasarkan waktu yang telah ditentukan. Penelitian yang ada dilapangan sehingga tidak mengutamakan besarnya populasi atau sampling serta populasi atau sampling yang digunakan terbatas. Jika data yang terkumpul sudah mendalam dan bisa menjelaskan penelitian ini, maka tidak perlu mencari sampling lainnya. Disini yang di tekankan adalah persoalan kedalam (kualitas) data bukan banyaknya (kuantitas data) (Kriyantono, 2006 :58). Selain itu biasanya penelitian menggunakan metode kualitatif data yang dikumpulkan lebih banyak berupa kata-kata atau gambar daripada angka-angka (Basrowi dan Suwandi, 2008 :187).

Beberapa teknik pengumpulan data yang digunakan dalam penelitian ini adalah :

\section{Data Primer}

Data primer adalah data yang diperoleh dari sumber data pertama atau tangan pertama di lapangan (Kriyantono, 2006: 43). Adapun cara untuk mendapatkan data primer yaitu :

Metode Wawancara Mendalam (InDepth Interview Method)

Wawancara secara mendalam secara umum adalah proses keterangan untuk tujuan penelitian dengan cara Tanya jawab sambil bertatap muka antara pewawancara dengan informan atau dengan orang yang diwawancarai, dengan atau tanpa menggunakan pedoman wawancara, dimana pewawancara informan terlibat dalam kehidupan sosial yang relatif lain. Dengan demikian, kekhasan wawancara mendalam adalah 
terlibatnya dalam kehidupan informan (Bungin, 2006: 18).

Metode Observasi

Observasi adalah kemampuan seseorang untuk menggunakan pengamatannya melalui hasil kerja pancaindra mata dibantu oleh pancaindra lainnya. Metode observasi adalah metode pengumpulan data yang digunakan untuk menghimpun data penelitian melalui pengamatan dan pengindraan. Menurut Bungin (2008 : 55) suatu kegiatan pengamatan baru dikategorikan sebagai kegiatan pengumpulan data penelitian apabila memiliki kriteria sebagai berikut :

Pengamatan digunakan dalam penelitian dan telah direncanakan secara serius.

Pengamatan harus berkaitan dengan tujuan penelitian yang telah ditetapkan.

Pengamatan dicatat secara sistematik dan dihubunenggakan dengan proporsi umum dan bukan dipaparkan sebagai sesuatu yang hanya menarikperhatian.

Pengamatan dapat di cek dan dikontrol mengenaikeabsahannya.

Dengan demikian peneliti dapat mendokumentasikan kegiatan informan sebagai data pendukung dalam penelitian ini.

\section{Data Sekunder}

Data sekunder didapat dengan cara mempelajari dan mengumpulkan data melalui :

Metode kepustakaan

Metode kepustakaan dilakukan dengan cara mempelajari dan mengumpulkan data melalui literatur. Data yang diperoleh melalui tinjauan pustaka dengan mempelajari buku-buku, jurnal, dan sebagainya yang dianggap punya relevansi dengan fokus masalah yang mendukung penelitian.

\section{Metode Dokumentasi}

Melakukan penelitian dengan mengumpulkan data-data berupa video atau foto yang terkait kajian penelitian. Data dapat berupa berita atau sesuatu yang di siarkan di media massa.

Pemilihan informan sebagai sumber data dalam penelitian ini adalah berdasarkan pada asas subyek yang menguasai permasalahan, memiliki data, dan bersedia memberikan imformasi lengkap dan akurat. Informan yang bertindak sebagai sumber data dan informasi harus memenuhi syarat, yang akan menjadi informan narasumber (key informan) dalam penelitian ini adalah Pekerja Seks Komersil di kota Medan. Didalam penelitian kualitatif, jumlah informan tidak menjadi persoalan tetapi tergantung dari tepat tidaknya pemilihan informan kunci, dan komplesitas dari keragaman fenomena sosial yang diteliti.

\section{Mengingat}

keterbatasan

kemampuan, waktu, dan biaya, maka penulis meggunakan metode purposive sampling dalam penulisan tugas akhir ini. Penelitian ini menentukan informan dengan menggunakan purposive sampling. Purposive sampling adalah metode pengambilan sampel yang dipilih dengan cermat sehingga relevan dengan struktur penelitian, dimana pengambilan sampel dengan mengambil sample orang-orang yang dipilih oleh penulis menurut ciri-ciri spesifik dan karakteristik tertentu(Djarwanto,1998: 30).

Selain itu purposive (secara sengaja) juga dapat diartikan sebagai teknik penentuan sampel dengan pertimbangan 
tertentu. Teknik ini bisa diartikan sebagai suatu proses pengambilan sampel dengan menentukan terlebih dahulu jumlah sampel yang hendak diambil, kemudian pemilihan sampel dilakukan dengan berdasarkan tujuan-tujuan tertentu, asalkan tidak menyimpang dari ciri-ciri sampel yang ditetapkan ( Sugiyono 2008 : 85). Adapun yang menjadi kriteria atau ciri - ciri informan adalah sebagai berikut :

1. Bekerja sebagai Pekerja Seks Komersil lebih dari 1 tahun

2. Pekerja Seks Komersial yang berada di pinggir jalan

3. Pekerja Seks Komersial yang berada di Kota Medan.

\section{HASIL DAN PEMBAHASAN}

Dalam penelitian kualitatif analisis data merupakan tahap yang bermanfaat untuk menelaah data yang telah di peroleh dari beberapa informan yang telah di pilih selama penelitian berlangsung. Selain itu juga berguna untuk menjelaskan dan memastikan kebenaran temuan penelitian. Analisis data ini telah dilakukan sejak awal dan bersamaan dengan proses pengumpulan data di lapangan.

Adapun penelitian yang telah dilakukan, peneliti mendapatkan beberapa temuan yang dapat mengambarkan bagaimana pengelolaan kesan dan citra diri Pekerja Seks Komersial dari kacamata komunikasi yang terlihat dari hasil wawancara dan observasi dimana pengelolaan kesan dan citra diri terjadi pada Pekerja Seks Komersial pinggir jalan kota Medan.

Secara teknis, pengelolaan kesan dan citra diri melibatkan Pekerja Seks Komersial sebagai yang menjadi narasumber inti dari penelitian ini. Komunikasi dilakukan dalam suasana nyantai dan rileks. Hasil temuan data penelitian yang akan dipaparkan merupakan hasil reduksi data, dimana data yang ditampilkan adalah data yang dianggap peneliti dapat menjawab fokus masalah dan tujuan penelitian ini sebagaimana dimaksud pada BAB I. Untuk memudahkan dalam memahami hasil temuan maka peneliti akan memaparkannya secara point per point yang disesuaikan dengan aspek kajian pada BAB III dan masing-masing informan. Peneliti tidak dapat menjabarkan secara detail mengenai identitas dari setiap informan peneliti karena setiap informan meminta segala sesuatu yang berkaitan dengan kepribadian mereka disamarkan dan diburamkan.
Tabel 4.2

Data Informan 


\begin{tabular}{|l|l|l|l|l|l|l|l|}
\hline N & Nama & $\begin{array}{l}\text { Ala } \\
\text { mat }\end{array}$ & $\begin{array}{l}\text { U } \\
\text { s } \\
\text { i } \\
\text { a }\end{array}$ & $\begin{array}{l}\text { Usi } \\
\text { me } \\
\text { nja } \\
\text { di } \\
\text { PSK }\end{array}$ & $\begin{array}{l}\text { Ag } \\
\text { am } \\
\text { a }\end{array}$ & $\begin{array}{l}\text { Suk } \\
\text { u }\end{array}$ & $\begin{array}{l}\text { Pekerjaan } \\
\text { di KTP }\end{array}$ \\
\hline 1 & Anna & $\begin{array}{l}\text { Tem } \\
\text { bung }\end{array}$ & $\begin{array}{l}2 \\
5\end{array}$ & 23 & $\begin{array}{l}\text { Isla } \\
\text { m }\end{array}$ & $\begin{array}{l}\text { Ace } \\
\text { h }\end{array}$ & $\begin{array}{l}\text { Ibu Rumah } \\
\text { Tangga }\end{array}$ \\
\hline 2 & Tina & $\begin{array}{l}\text { Amp } \\
\text { las }\end{array}$ & $\begin{array}{l}3 \\
5\end{array}$ & 19 & $\begin{array}{l}\text { Isla } \\
\text { m }\end{array}$ & $\begin{array}{l}\text { Min } \\
\text { Jaw } \\
\text { Ja }\end{array}$ & $\begin{array}{l}\text { Wiraswast } \\
\text { a }\end{array}$ \\
\hline 3 & Sulis & $\begin{array}{l}\text { Krak } \\
\text { atau }\end{array}$ & $\begin{array}{l}4 \\
0\end{array}$ & 30 & $\begin{array}{l}\text { Isla } \\
\text { m }\end{array}$ & $\begin{array}{l}\text { Jaw } \\
\text { a }\end{array}$ & $\begin{array}{l}\text { Ibu rumah } \\
\text { tangga }\end{array}$ \\
\hline Cintya & $\begin{array}{l}\text { Panc } \\
\text { ing }\end{array}$ & $\begin{array}{l}1 \\
8\end{array}$ & 16 & $\begin{array}{l}\text { Kri } \\
\text { ste } \\
\text { n }\end{array}$ & $\begin{array}{l}\text { Ma } \\
\text { nad } \\
\text { o }\end{array}$ & - \\
\hline 5 & Yuni & $\begin{array}{l}\text { Sung } \\
\text { gal }\end{array}$ & $\begin{array}{l}2 \\
9\end{array}$ & 25 & $\begin{array}{l}\text { Kri } \\
\text { ste } \\
\text { n }\end{array}$ & $\begin{array}{l}\text { Bat } \\
\text { ak } \\
\text { jaw } \\
\text { a }\end{array}$ & $\begin{array}{l}\text { Wiraswast } \\
\text { a }\end{array}$ \\
\hline
\end{tabular}

Berikut ini adalah temuan penelitian yang diperoleh dari hasil wawancara mendalam dengan para informan.

\section{SIMPULAN}

Adapun kesimpulan yang dapat di ambil dari penelitian ini adalah :

1. Pengelolaan kesan yang dibentuk kelima informan di depan pelanggan saat sedang melakukan pertunjukkan (panggung depan) di depan para lelaki hidung belang dilakukan dengan sengaja karena apa yang ditampilkan oleh kelima informan bertujuan untuk mendapat perhatian dari pria hidung belang. Pengelolaan kesan oleh kelima informan di pinggir jalan saat panggung depan di kota Medan meliputi : bahasa tubuh dan intonasi suara, bahasa verbal, gaya bicara, ekspresi wajah dan setting serta penampilan. Panggung belakang dari kelima informan tentu ketika ia mempersiapkan dan memperlihatkan dirinya yang sebenarnya seperti halnya berganti kostum sebelum bekerja dan sebelum pulang kerumah. Citra diri kelima informan didepan pelanggan merupakan perempuan yang tidak berkemampuan dan berkepribadian rendah.

2. Pengelolaan kesan yang ingin dibentuk oleh kelima informan saat berada dipanggung depan atau ketika sedang berinteraksi dengan keluarga adalah menjadi seseorang yang baik dalam hal materi, status dan pandangan orang lain kepada mereka. Panggung depan yang dibentuk adalah wanita yang "baikbaik" dan mempunyai status keuangan yang baik sedangkan panggung belakang dari kelima informan adalah ketika ia kembali berganti kostum menjadi seorang yang seperti biasanya dikenal oleh keluarga. Citra diri mereka akan tetap baik didepan keluarga jika pekerjaan mereka tidak diketahui oleh keluarga.

3. Pengelolaan kesan yang ingin dibentuk oleh pekerja seks komersial di panggung depan lingkungan sekitar adalah menjadi orang yang mempunyai uang sehingga keberadaannya tidak di sudutkan atau didiskriminasi serta menganggkat derajat keluarga secara ekonomi. Selama kelima informan dapat menyembunyikan pekerjaannya dari lingkungan sekitarnya maka selama itu citra diri kelima informan akan baik. 


\section{DAFTAR PUSTAKA}

A.Javier Trevino; George C. Homans. (2006). History, Theory, And Method, Paradigm Publisher

Alwasilah. A. C. (2002). Pokoknya Kualitatif : DasarDasar Merancang dan Melakukan Penelitian Kualitatif. Jakarta : PT Dunia Pustaka Jaya

Amaryllia Puspasari. (2007). Mengukur Konsep Diri Anak. Jakarta: PT ElexMedia Komputindo.

Anonima. 2004. Keputusan Menteri Kesehatan RI, No.1204/MENKES/SK/X/2004, tentang Persyaratan Kesehatan Lingkungan Rumah Sakit.

Anselm. Strauss, Corbin. Juliet. (2003). Dasar Dasar Penelitian Kualitatif. Yogyakarta: Pustaka Pelajar

Arni, Muhammad. (2009). Komunikasi Organisasi. Jakarta: Bumi Aksara

Baron, R. A. \& Byrne, D. (2004). Psikologi Sosial (edisi 10). Jakarta :PenerbitErlangga (2000). Social Psychology. (9th Edition).Massachusetts: A Pearson Education Company

Basrowi \& Suwandi. (2008). Memahami Penelitian Kualitatif. Jakarta: Rineka Cipta

Beebe, Steven A, Susan J. Beebe, Mark V. Redmond. ( 2005). Interpersonal Communication : Relating to Others Fourth Edition. Boston : Pearson Education, Inc.

Berger, Charles R; Michael E. Roloff; dan David R Roskos-Ewoldsen. (2014).Handbook Ilmu Komunikasi (Terj. Derta Sri Widowatie). Bandung: Nusa Media.

Breckler, S., Olson, J. M., \& Wiggins, E. C. (2006). Social Psychology Alive.United States: Thomson.

Bronislaw Malinowski, Kula. (2007). The Circulating Exchange of Valuables in the Archipelagoes of Eastern New Guinea. Man

Budyatna. 2015. Teori-Teori Mengenai Komunikasi AntarPribadi. Jakarta:Kencana prenada media

Bungin, Burhan. (2006). Sosiologi Komunikasi: Teori, Paradigma danDiskursus Teknologi
Komunikasi di Masyarakat. Jakarta: Kencana Prenada Media Group.

(2008).Sosiologi Komunikasi (Teori, Paradigma, dan Discourse Teknologi Komunikasi di Masyarakat). Jakarta: Kencana Prenada Media Group.

Cahyadi. A \& Danardono. D. (2009). Cetakan I. Sosiologi Hukum dalamPerubahan.Yayasan Pustaka Obor Indonesia: Jakarta

Centi, J Paul. (1993). Mengapa Rendah Diri?. Yogyakarta: Kansius

Dayakisni, T. \& Hudaniah. (2003). Psikologi sosial. UniversitasMuhammadiyah: Malang.

Denzim, Norman K., and Lincoln, Yvonna S. (2009). Handbook of qualitativeresearch (terjemahan). Yogyakara Pustaka Pelajar.

Devito, Joseph, A. (1997). Human Communication. New York: HarperCollinc Colege Publisher.

Dhita Sekar Annisa. 2016. Presentasi Diri Pekerja Seks Komersial Emporium

Jakarta: Jurnal Ilmu Komunikasi. 67-100

Dianawati, Ajen. (2003). Pendidikan Seks untuk Remaja. Jakarta: KawanPustaka

Djarwanto, PS. dan Subagyo Pangestu., (1998). Statistik Induktif. BPFE; Jakarta

Elva Ronaning Roem. 2014. Pengelolaan Kesan Oleh Pekerja Seks Komersial.

Padang : Jurnal Ilmu Komunikasi. Vol.5, No.1 :7387

Fajar, Marhaeni. (2009). Ilmu Komunikasi Teori dan Praktek Edisi Pertama. Yogyakarta : Graha Ilmu

Ghony, M.D. dan Almanshur, F. (2012). Metodologi Penelitian Kualitatif. Yogyakarta: Ar-ruzz Media

Griffin, Em. (2006). A First Look at Communication Theory. USA: McGrawHill.

Gunawan, W adi.(2003). Cetakan I. Born to be a Genius. Jakarta : Gramedia

Pustaka Utama.

Hadiwibowo, U. (2003). Mewujudkan Pribadi yang Berharga. Jakarta: Indo Persada. 
Hasan, M. Iqbal. (2002). Pokok-pokok Materi Metodologi Penelitian dan Aplikasinya. Bogor : Ghalia Indonesia.

Hurlock, E. B. (1976). Personality Development. McGrow; Hill New DelhiPublishing Company Ltd.

Rakhmat, Jalaludin. (2005). Psikologi Komunikasi. Bandung: PT. RemajaRosda Karya

(2013). Metode penelitian Komunikasi. Bandung: PT.Remaja Rosda Karya

Jersild, T. Arthur. (1961). The Growing Self: The Psychology Adolesence(2nd ed) pretince. Hall Inc: Englewood Cliffs

Johnson, Paul, Doyle. (1996). Teori Sosiologi Klasik dan Modern 2, AlihBahasa M.Z. Lawang, Jakarta: Gramedia

Jonathan H. Turner; Peter R. Turner. (1998). The Structure of Sociological Theory, Sociology Series, Wadsworth Pub.Co

Kartono, Kartini. (2011). Patologi Sosial Jilid 1. Jakarta: PT Rajagrafindo Persada.

Koentjaraningrat. (2004). Manusia dan Kebudayaan di Indonesia. Jakarta :PT Rineka Cipta

Koentjoro. (2004). On The Spot: Tutur dari Seorang Pelacur. Yogyakarta: CV Qalams

Kreitner, Robert dan Kinicki, Angelo. (2005). Perilaku Organisasi, buku 1 dan 2, Jakarta : Salemba Empat.

Kriyantono, Rachmat. (2006). Teknik Praktis Riset Komunikasi. Jakarta:Kencana

Lazowski, L.E and S.M Andersen. (1990). "SelfDisclosure and Social Perception: The Impact of Private, Negative, and Extreme Communications", dalam Journal of Social Behavior and Personality, 5. International Journal of Psychology.

Liliweri, Alo. (2011). Komunikasi: Serba Ada Serba Makna. Jakarta:Kencana.

Moleong, J Lexy. (2005). Metodologi Kualitatif Edisi Revisi. Bandung: PT Remaja Rosdakarya

(2009). Metode Penelitian Kualitatif. Bandung : PT. Remaja Rosdakaya

Mulyana, Dedy. (2003). Ilmu Komunikasi Suatu Pengantar. Bandung: Rosdakarya
Pace, R. Wayne \&Don F. Faulos. (2006). Komunikasi Organisasi: Strategi meningkatkan kinerja perusahaan (editor Deddy Mulyana, MA, Ph.D.). PT Remaja Rosdakarya : Bandung

Patilima, Hamid. (2005). Metode Penelitian Kualitatif. Bandung: Alfabeta.

Prasetyo, bambang. (2006). Metode Penelitian Kuantitatif : Teori dan Aplikasi.Raja Grafindo Persada : Jakarta.

Pudjijogyanti, CR. (1998). Konsep Diri Dalam Pendidikan. Jakarta : Arcan.

Retalia, Okta and Dedi, Supriyadi and Heri, Supriyanto.2013. Pengelolaan Kesan

Penyiar Radio (Studi Dramaturgi tentang Pengelolaan Kesan pada Penyiar Radio Lesitta di Kota Bengkulu). Bengkulu : Jurnal IlmuKomunikasi. 4-77

Riyanto, Theo. (2010). Cetakan I. Memotivasi Diri: Langkah Menuju Sukses. Yogyakarta : Penerbit Kanisius.

Ryandry purnawan.2014. Presentasi diri seorang pekerja seks komersial (Studi

Kualitatif Metode Dramaturgi Mengenai Presentasi Diri Seorang Pekerja Seks Komersial di Saritem Bandung). Bandung: Jurnal Komunikasi Konsentrasi Jurnalistik. 1-14.

Salim, Agus. (2006). Teori dan Paradigma Penelitian Sosial.Yogyakarta:Tiara Wacana.

Severin, Werner J \& Tankard, James W. (2005). Teori Komunikasi: Sejarah,Metode, \& Terapan di Dalam Media Massa, Edisi Ke-5. Jakarta: Kencana.

Sugiyono. (2005). Metode Penelitian Bisnis. Bandung: Alfabeta (2008). Metode Penelitian Kunatitatif Kualitatif dan R\&D.Bandung Alfabeta.

Surip, M. (2011).Teori Komunikasi: Perspektif Teoritis Teori Komunikasi.Medan: Unimed.

Susanto, A.B. (2001). Potret-Potret Gaya Hidup Metropolis. Jakarta :Penerbit Kompas 
Tahir, Muh, 2011. Pengantar Metodologi Penelitian Pendidikan. Makassar : Universitas Muhammadiyah Makassar.

Taylor, Shelley E., Letitia Anne Peplau \& David 0. Sears. (2009). Psikologi

Sosial Edisi Kedua Belas. Jakarta: Kencana Prenada Media Group

Yanti. (2000). Konsep Diri Perempuan Marjinal. Skripsi. UGM: Yogyakarta.

Yin, Robert K, (2008), Studi Kasus (Desain Dan Metode), (Case Study

ResearchDesign and Methods") diterjemahkan oleh Drs. M. Djauzi Mudzakir, MA, ,Jakarta : PT.Raja Grafindo Persada

Weller Seward E. Miller. (2002). Textbook of Clinical Pathology. Eightedition/Asian edition. Igaku Shoin, Ltd: Tokyo.

Widyastuti, Yani dkk. (2009). Kesehatan Reproduksi. Yogyakarta: Fitramaya.

Sumber Kajian lainnya :

Sumber:

http://www.muslimedianews.com/2016/02/cara -penulisan-dan-contohdaftar.html\#ixzz4vOGjtIqu

https://m.tempo.co/read/news/2013/04/16/05

8473745/40-juta-psk-

menghunilokalisasi-di-seluruh-

indonesia. di unduh 2017-03-28

http://koran-

sindo.com/news.php? $\mathrm{r}=0 \& \mathrm{n}=4 \&$ date $=2$ $016-02-29 ? \mathrm{r}=0 \& \mathrm{n}=4 \&$ date $=2016-02-$

29 di unduh pada tanggal 12-04-2017 pukul 22.12 WIB judulnya Belanja Prostitusi orang indonesia Rp 30 triliun/tahun

http://merahputih.com/post/read/wowjumlah-psk-di-indonesia-capai-56-ribu di unduh pada tanggal 12-04-2017 pukul 22.16 WIB judulnyaWOW, jumlah PSK di Indonesia mencapai 56 ribu

http://psikologi.or.id/mycontents/uploads/201 0/07/hubungan-interpersonal.pdf di unduh pada tanggal 12-04-2017 pukul 21.00 WIB 